\title{
Spawalność stali i kryteria jej oceny
}

\section{Weldability of steels and criterion of its estimation}

\section{Streszczenie}

W artykule przeprowadzono analizę terminu spawalność, dokonano doboru metod oceny spawalności stali, przeanalizowano rozumienie i traktowanie przez różnych badaczy terminu spawalność i wskazano opinię autorów o możliwej liczbowej ocenie spawalności. Uzasadniono wzajemny związek spawalności wykorzystywanych materiałów inżynierskich z technologią i konstrukcją. Ustalono następujące poziomy spawalności: dostateczna (wszystkie eksploatacyjne wymagania spełnione); niedostateczna (chociażby 1 wymóg niespełniony); dobra; zadowalająca (konieczność zmiany warunków spawania); ograniczona (konieczność zmiany sposobu spawania); zła (nie ma możliwości osiągnięcia pozytywnego wyniku).

\section{Abstract}

It has been analized the term of weldiability, selected the methods of steels weldiability estimation, compared the understanding and applications by different investigators the term of weldiability, presented the authors opinion about numerical estimation of weldiability. Grounded the mutual connnection of using materials weldability with technology and construction. It has been established the weldability levels: acceptable (all service requirements have satisfied); non acceptable (even 1 service requirement has not satisfied); good; compatible (to change the welding circumstances); limited (to change the weIding methods); bad (no possibility to achieve the positive results).

\section{Wstęp}

Praktyka spawalnicza wskazuje, że nie wszystkie stale są dobrze spawalne. Jedne wykazują dobre właściwości spawalnicze bez jakichkolwiek ograniczeń, do spawania innych należy stosować specjalne techniki. W związku z tym właściwość stali, którą nazywa się ogólnie spawalnością, może być różna. Stąd też istnieje dosyć szerokie traktowanie tego pojęcia.

Według standardu ISO [1] metal można uważać za spawalny, jeśli przy spawaniu osiąga się spójność połączenia spawanego i przy czym stosuje się taki proces spawania, który pozwala otrzymać połączenia spełniające postawione im wymogi dotyczące właściwości.

Według standardu Brytyjskiego Instytutu Spawania (BIS) [2] spawalność - to zdolność materiału do poddawania się spawaniu dowolnym sposobem bez specjalnych środków w celu otrzymania połączenia, właściwości którego pozwalają w całości wykorzystać materiał.

Prof. dr hab. inż. Gieorgij M. Grigorenko, dr inż. Walery A. Kostin - Instytut Elektrospawalnictwa im. Je.O. Patona Państwowej Akademii Nauk w Kijowie.
Według standardu DIN [3] (Niemcy) spawanie detali z metalowych materiałów ma miejsce, jeśli za pomocą pewnego sposobu spawania i przy dotrzymaniu pewnej technologii osiąga się łączenie materiałów przy dotrzymaniu wymaganych właściwości złączy spawanych i ich wpływu na konstrukcję.

Rosyjskie określenie spawalności zgodnie z normą państwową 29273-92 [4]: metalowy materiał jest uważany za spawalny, jeśli poddaje się spawaniu do ustalonej miary przy takich procesach i do takiego celu, kiedy spawaniem osiąga się metalową całość przy odpowiednim procesie technologicznym, a spawane detale odpowiadają technicznym wymogom pod względem jakości, jak i względem wpływu na konstrukcję, którą tworzą. Zbliżona do tej jest również definicja ukraińska, określona w DSTU [5].

Mając na uwadze powyższe, pojęcie spawalności musi łączyć cztery współzależne czynniki: rodzaj materiału, typ konstrukcji, konieczne (niezbędne) właściwości i poziom spawalności (miara pewności). Zależnie od ich wyboru i powiązania będzie osiągalny określony poziom spawalności [6].

Swój punkt widzenia na spawalność mają poszczególni uczeni-spawalnicy. Znaczny wkład do systematyzacji terminu spawalność i metod jej oceny wniósł K.A. Yushchenko. Na podstawie analizy istniejących 
podejść do oceny spawalności i obowiązujących w różnych krajach i organizacjach standardów, w [7, 8] zaproponowano nowe rozumienie tego terminu. Wykazano, że w absolutnej większości przypadków spawalność ocenia się jakościowo i subiektywnie; termin spawalność rozpatruje się szerzej niż tezy filozoficzne, a wyznaczenie spawalności przez zdolność materiału do tworzenia połączenia spawanego nie wskazuje wymiernych i mierzalnych cech.

Asnis [9] określa spawalność w następujący sposób: spawalność materiałów rozpatruje się jak ogólne pojęcie, charakteryzujące się przydatnością do spawania i pewnością połączenia spawanego.

Szorszorow ze współpracownikami [10] dają taką ocenę spawalności: spawalność tego lub innego materiału tym jest lepsza, im większa jest liczba możliwych sposobów ich spawania, im prostsza technologia i szersze zakresy dopuszczalnych parametrów spawania, prowadzące do uzyskania zadanych właściwości połączenia spawanego.

Zgodnie z Musijaczenką i Michodujem [11]: ocena spawalności wysokowytrzymałych stali sprowadza się do wyznaczenia optymalnych warunków spawania, przy których uniemożliwia się pojawienie się w połączeniu spawanym pęknięć, a metal w strefie wpływu ciepła zachowuje wymaganą plastyczność, wytrzymałość i udarność.

Herold [12] wykazał zasadniczo odmienne podejście do pojęć spawalności i złącza i określił miejsce spawalności w kształtowaniu połączenia spawanego.

Przeprowadzona analiza prac o spawaniu stali i stopów pokazuje, że spawalnicy również szeroko wykorzystują takie pojęcia, jak spawalność hutnicza, fizyczna i technologiczna.

\section{Przebieg i wyniki badań}

Spawalność hutnicza $[13,14]$ odznacza się procesami, w których następuje wymieszanie ciekłego metalu spoiny w spawanych detalach, wskutek czego tworzy się spójne połączenie spawane. Na granicy styku łączonych detali zachodzą procesy fizykochemiczne mieszania, które określane są przez właściwości łączonych metali. Jednorodne metale (o podobnym składzie chemicznym) wykazują jednakową hutniczą spawalność. Spawanie różnorodnych metali może okazać się niemożliwe, ponieważ ze względu na właściwości takich metali czasami nie jest możliwe zapewnienie koniecznych procesów fizykochemicznych w strefie topienia - te metale nie mają hutniczej spawalności.

Przez spawalność fizyczną autorzy prac $[15,16]$ rozumieją możliwość otrzymania jednolitych połączeń spawanych pod względem chemicznym. Taką spawalność mają praktycznie wszystkie techniczne stopy i czyste metale, a także szereg połączeń metali z niemetalami.

Spawalność technologiczna $[17,18]$ to charakterystyka metalu, która wyznacza jego reakcję na działanie spawania i zdolność tworzenia połączeń spawanych z zadanymi eksploatacyjnymi właściwościami. W tym wypadku spawalność rozpatruje się jako miarę zgodności właściwości połączeń spawanych z właściwościami głównego metalu lub ich normatywnym znaczeniom. Według standardu DIN [3] (Niemcy) spawalność detali z materiałów metalowych jest uzależniona od dalej wskazanych czynników (rys. 1).

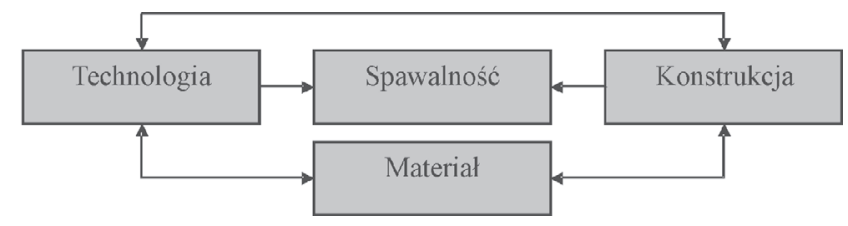

Rys. 1. Wzajemny związek spawalności wykorzystywanych materiałów z technologią i konstrukcją

Fig. 1. Mutual connnection of using materiałs weldability with technology and construction

Przy tworzeniu złączy rozróżnia się następujące poziomy spawalności zgodnie z Makarowem [19] (rys. 2). Przydatność stali do spawania wyznacza się testami na spawanie, które w większości wypadków zastępują badania skłonności do tworzenia pęknięć różnego typu. Na przykład, dla połączeń spawanych węglikowych i stali stopowanych przyjmowane są następujące wskaźniki spawalności:

- odporność na pękanie gorące (GP);

- odporność na pękanie zimne (ZP);

- odporność na pękanie lamelarne (LP);

- odporność na pękanie po obróbce cieplnej (POC);

- znaczenie głównych właściwości mechanicznych spoiny i strefy wpływu ciepła (SWC);

- odporność na rozwój pęknięć (DTP);

- inne wskaźniki charakterystyczne dla właściwości roboczych obciążeń i warunków eksploatacji (wytrzymałość przy cyklicznych obciążeniach, udarność przy eksploatacji w warunkach obniżonej temperatury itp.).

Uważane za dostateczne wskaźniki spawalności materiału są te, które są równe lub wyższe od normatywnych wartości koniecznych właściwości według technicznych warunków eksploatacji tego typu konstrukcji spawanych. Jeśli wszystkie wskaźniki spawalności są dostateczne (wszystkie wymogi eksploatacyjnych właściwości połączeń spawanych zgodne z przyjętymi dopuszczeniami), to spawalność materiałów jest uważana za dostateczną. Jeśli nie są określane minimalne możliwe do przyjęcia poziomy chociażby jednego ze wskaźników spawalności, wówczas spawalność materiału klasyfikuje się jako niedostateczną. Należy wskazać, że przy takim podejściu spawalność tego samego materiału może być różnie oceniona, zależnie od przeznaczenia wyrobu.

Znaczny wpływ na spawalność wywierają skład chemiczny stali czy stopu, skład strukturalno-fazowy i jego przemiany podczas grzania i oziębiania, fizykochemiczne i mechaniczne właściwości, aktywność elementów w stosunku do tlenu, węgla i innych pierwiastków. 


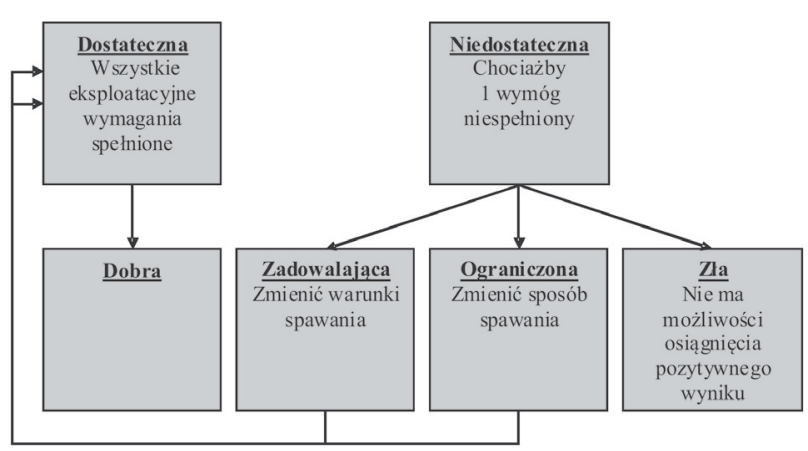

Rys. 2. Poziomy spawalności: dostateczna (wszystkie eksploatacyjne wymagania spełnione); niedostateczna (chociażby 1 wymóg niespełniony); dobra; zadowalająca (zmienić warunki spawania); ograniczona (zmienić sposób spawania); zła (nie ma możliwości osiągnięcia pozytywnego wyniku)

Fig. 2. Weldability levels: acceptable (all service requirements has satisfied); non acceptable (even 1 service requirements has not satisfied); good; compatable (to change the welding sircumstances); limited (to change the welding methods); bad (no possibility toachive the positive results)

W związku z tym, że parametrów, które charakteryzują materiał podstawowy i dodatkowy jest bardzo dużo, to spawalność przedstawia kompleksową charakterystykę, która wyklucza podatność metalu na utlenianie i tworzenie porowatości, zapewnia odpowiednie właściwości połączenia spawanego zgodnie $z$ wymogami właściwości eksploatacyjnych, reakcję na cykle termiczne, odporność na pękanie zimne i gorące itp.

Z przedstawionych parametrów najbardziej znacząca przy spawaniu i napawaniu węglowych i niskostopowych stali jest odporność na tworzenie pęknięć. Spawalność musi uwzględniać odporność metalu spoiny na tworzenie pęknięć gorących, zimnych i lamelarnych oraz pęknięć na skutek ponownego ogrzania.

Gorące pęknięcia najczęściej powstają przy osłabieniu plastyczności metalu przez pojawienie się w strukturze łatwo topliwych kruchych eutektyk, defektów krystalicznej budowy, naprężeń wewnętrznych i obciążeń zewnętrznych.

Wilkinson [20] zaproponował, by dla węglowych i niskostopowych stali wykorzystać wskaźnik H.C.S. (hot cracking susceptibility) skłonności stali do tworzenia pęknięć gorących:

$$
\text { H.C.S. }=\frac{\% \mathrm{C} \cdot(\% \mathrm{~S}+\% \mathrm{P}+\% \mathrm{Si} / 25+\mathrm{Ni} / 100)}{3 \% \mathrm{Mn}+\% \mathrm{Cr}+\% \mathrm{Mo}+\% \mathrm{~V}} \cdot 10^{3}
$$

Przy zwyczajnym spawaniu stali niskostopowej pęknięcia zaczynają powstawać przy H.C.S. > 4 [21].

Do sposobów zmniejszenia ryzyka tworzenia się pęknięć gorących zalicza się takie metody, jak: obniżenie zawartości siarki, fosforu, węgla, podwyższenie zawartości $\mathrm{Mn}$, stosowanie stali austenitycznych, stworzenie możliwości powstania pierwotnej struktury ferrytycznej.

Zimne pęknięcia najczęściej powstają wskutek hartowania stali, przy szybkim oziębieniu i nasycaniu metalu spoiny i strefy wpływu ciepła wodorem. Pęknięcia te $z$ reguły pojawiają się po pewnym czasie po spawaniu lub napawaniu i rozwijają się w ciągu kilku godzin albo nawet doby.
Wśród metod oceny skłonności metalu do pojawienia się pęknięć zimnych najczęściej wykorzystuje się równoważnik węgla, z którego można korzystać jak ze wskaźnika charakteryzującego spawalność stali.

Do oceny skłonności stali do tworzenia pęknięć zimnych Olson i Cohen [22] założyli wykorzystywanie szeregu wskaźników.

Równoważnik węgla, zaproponowany przez Międzynarodowy Instytut Spawalnictwa [23], który wykorzystuje się dla stali niskostopowych zawierających nie więcej niż $0,18 \%$ (mas.) węgla, lub gdy czas oziębienia w przedziale temperatury $800 \div 500^{\circ} \mathrm{C}$ nie przekracza 12 s., wynosi:

$$
\mathrm{C}_{e}=\% \mathrm{C}+\% \mathrm{Mn} / 6+(\% \mathrm{Ni}+\% \mathrm{Cu}) / 15+(\% \mathrm{Cr}+\% \mathrm{Mo}+\% \mathrm{~V}) / 5
$$

Ito Bessyo [24] dla stali o zawartości poniżej 0,22\% (mas.) węgla i w przy szybkim oziębianiu (czas oziębienia $\mathrm{w}$ przedziale temperatury $800 \div 500^{\circ} \mathrm{C}$ poniżej 6 s.) zaproponowali wykorzystanie wskaźnika $P_{c m}$ :

$$
\begin{aligned}
P_{c m}= & \% C+\% \text { Si } 30+(\% M n+\% C u+\% C r) / 20+ \\
& +\% N i / 60+\% M o / 15+\% V / 10+5 \% B
\end{aligned}
$$

Często wykorzystuje się inną postać wzoru (3):

$$
\begin{aligned}
C_{e}= & \% C+\% \text { Si } / 25+(\% M n+\% C u) / 20+\% C r / 10+ \\
& +\% N i / 40+\% M o / 15+\% V / 10
\end{aligned}
$$

Yurioka, Ohsita i Tamehiro [25] dla stali o zawartości do $0,25 \%$ (mas.) węgla zaproponowali korzystanie ze wskaźnika równoważnika węgla określonego wzorem:

$$
\begin{aligned}
C_{e}= & \% C+A(\% C) \cdot(\% S i / 24+\% M n / 6+\% C u / 15+\% N i / 20)+ \\
& +(\% C r+\% M o+\% N b+\% V) / 5+5 \% B
\end{aligned}
$$

gdzie: $A(\% C)=0,75+0,25$ th $(20(\% C-0,12))$.

Wzór (5) łatwo przekształca się na wzory $(2 \div 4)$, ponieważ parametr $A$ istotnie zależy od zawartości węgla w stali. Należy również zaznaczyć, że tworzenie hartowniczych mikrostruktur i związanych z nimi pęknięć zimnych zależy od szybkości oziębienia metalu spoiny i strefy wokół niej, na którą wpływają cieplne parametry spawania (dostarczenie ciepła, początkowa temperatura) i konstrukcyjne właściwości połączenia (kształt, grubość). Przy spawaniu stali z wysokim równoważnikiem węgla, wraz ze wzrostem szybkości oziębienia prawdopodobieństwo tworzenia hartowniczych mikrostruktur zwiększa się, co znajduje odzwierciedlenie w równomiernym wzroście maksymalnej twardości w SWC. Ograniczenie maksymalnej twardości określoną krytyczną wartością może służyć jako korzystne kryterium do wyboru stali i warunków jej stosowania. Przykładowo, w japońskich normach z 70. lat XX. w. na stal na konstrukcje spawane, oprócz ograniczeń węgla, wprowadzono ograniczenie maksymalnej twardości w SWC, która nie może przekraczać 350 HV. 
Tablica I. Klasyfikacja stali wg spawalności

Table I. Classifications of steels due to weldability

\begin{tabular}{|c|c|c|c|c|c|c|}
\hline \multirow{3}{*}{$\begin{array}{c}\text { Grupa } \\
\text { stali }\end{array}$} & \multirow{3}{*}{ Spawalność } & \multirow{3}{*}{$\begin{array}{c}\text { Równoważnik węgla } \\
\text { wg wzoru (2) } \\
C_{E}, \%\end{array}$} & \multicolumn{4}{|c|}{ Stosowane podejścia technologiczne } \\
\hline & & & \multicolumn{2}{|c|}{ Podgrzanie } & \multicolumn{2}{|c|}{ Obróbka cieplna } \\
\hline & & & $\begin{array}{c}\text { przed } \\
\text { spawaniem }\end{array}$ & $\begin{array}{l}\text { podczas } \\
\text { spawania }\end{array}$ & $\begin{array}{c}\text { przed } \\
\text { spawaniem }\end{array}$ & po spawaniu \\
\hline 1 & dobra & $<0,2$ & - & - & - & pożądana \\
\hline 2 & zadowalająca & $0,2 \div 0,35$ & potrzebne & - & pożądana & potrzebna \\
\hline 3 & ograniczona & $0,35 \div 0,45$ & potrzebne & pożądane & potrzebna & potrzebna \\
\hline 4 & zła & $>0,45$ & potrzebne & potrzebne & potrzebna & potrzebna \\
\hline
\end{tabular}

Klasyfikację stali wg spawalności przedstawiono w tablicy I.

Do pierwszej grupy zaliczane są najbardziej rozpowszechnione gatunki stali niskowęglowych $\left(C_{e} \leq 0,2\right)$, które mogą być spawane wg tradycyjnej technologii, tzn. bez podgrzewania wstępnego i w trakcie spawania, a także bez późniejszej obróbki cieplnej. Zalecenia wskazują, że:

- odlewane detale z dużą objętością napawanego metalu zaleca się spawać z pośrednią obróbką cieplną;

- dla konstrukcji, pracujących w warunkach statycznych obciążeń, obróbka cieplna po spawaniu nie jest wymagana;

- dla odpowiedzialnych konstrukcji, pracujących przy dynamicznych obciążeniach czy w wysokiej temperaturze, zaleca się obróbkę cieplną.

Do drugiej grupy zaliczane są stale węglowe i stopowane $\left(C_{e}=0,2 \div 0,35\right)$, przy spawaniu których w normalnych warunkach produkcji nie występują zimne pęknięcia. Stal w tej grupie stali należy w celu uniknięcia pęknięć zimnych podgrzewać wstępnie, a także poddawać późniejszej obróbce cieplnej po spawaniu. Warunki prowadzenia obróbki cieplnej są różne i uzależnione od gatunku stali i konstrukcji detalu. Na przykład dla stali 30L w stanie lanym obróbka jest obowiązkowa jest to wyżarzanie. Detale maszyn z odlewów, niemających ostrych krawędzi, można spawać w stanie po obróbce cieplnej (hartowanie). Spawanie przy temperaturze otoczenia poniżej $0^{\circ} \mathrm{C}$ nie jest zalecane. Spawanie detali z dużą objętością napawanego metalu zaleca się wykonywać z pośrednią obróbką cieplną (wyżarzanie lub wysokie odpuszczanie).

W przypadku, gdy nie jest możliwe późniejsze odpuszczanie, spawane detale poddawane są miejscowemu grzaniu. Obróbka cieplna po spawaniu jest różna dla różnych gatunków stali. Przy zaspawaniu drobnych defektów stali o zawartości węgla powyżej 0,35\%, do poprawy właściwości mechanicznych i obrabialności potrzebna jest obróbka cieplna (wyżarzanie lub wysokie odpuszczanie).

Do trzeciej grupy $\left(C_{e}=0,35 \div 0,45\right)$ zaliczane są stale węglowe i stopowane o strukturze perlitycznej, skłonne w zwyczajnych warunkach spawania do pęknięć zimnych. Spawalność stali tej grupy zabezpiecza się przy użyciu specjalnych technologicznych przedsięwzięć, polegających na obróbce cieplnej przed spawaniem i podgrzewaniu wstępnemu. Poza tym, większość wyrobów z tej grupy stali poddaje się obróbce cieplnej po spawaniu. Dla detali - odlewów i odkuwek - nie mających zwłaszcza ostrych krawędzi i złożonych węzłów, dopuszcza się spawanie w stanie po obróbce cieplnej (hartowanie i odpuszczanie).

Bez podgrzewania wstępnego takie stale można spawać w przypadkach, kiedy połączenia nie mają ostrych krawędzi, grubość ścianki wynosi poniżej $14 \mathrm{~mm}$, temperatura otoczenia powyżej $+5^{\circ} \mathrm{C}$ oraz złącza spawane mają charakter pomocniczy. We wszystkich innych przypadkach temperatura podgrzewania towarzysząca spawaniu czy napawaniu zależy od typu spawanego materiału i waha się średnio od 250 do $400^{\circ} \mathrm{C}[26]$.

Do czwartej grupy $\left(C_{e} \geq 0,45\right)$ zaliczane są perlityczne stale węglowe i stopowane (trudno spawalne, skłonne do pęknięć). Przy spawaniu tej grupy stali z użyciem tradycyjnych technologii nie zawsze osiąga się konieczne właściwości eksploatacyjne połączeń spawanych. Te stale charakteryzują się ograniczoną spawalnością i wymagają prowadzenia obróbki cieplnej, z podgrzewaniem w czasie spawania i późniejszą obróbką cieplną.

Jeśli ocena spawalności wg wskaźnika ekwiwalentu węgla wskazuje na skłonność stali do pojawienia się pęknięć zimnych, to należy przewidzieć podgrzewanie wstępne spawanych detali. Temperatura podgrzewania wstępnego może być określona zgodnie $z$ formułą Seferiana [27], która pozwala obliczyć temperaturę podgrzewania wstępnego połączenia spawanego w celu uniknięcia pęknięć zimnych:

$$
T=350 \sqrt{\left[C_{E o g}\right]-0,25}
$$

gdzie: $\left[\mathrm{C}_{\text {Eog }}\right]$ - ogólny równoważnik węgla; $\left[\mathrm{C}_{\text {Eog }}\right]=\left[\mathrm{C}_{\mathrm{e}}\right]_{\mathrm{c}}+\left[\mathrm{C}_{\mathrm{e}}\right]_{\mathrm{s}}$, $\left[\mathrm{C}_{\mathrm{e}}\right]_{\mathrm{c}}$ - równoważnik węgla, który zależy od składu chemicznego metalu, obliczonego zgodnie $\mathrm{z}$ jednym ze wzorów $(2 \div 5)$; $\left[\mathrm{C}_{\mathrm{e}}\right]_{\mathrm{s}}$ - równoważnik węgla, zależny od grubości metalu, obliczony wg wzoru: $\left[\mathrm{C}_{\mathrm{e}}\right]_{\mathrm{s}}$ $=0,005 \delta\left[\mathrm{C}_{\mathrm{E}}\right]_{\mathrm{c}}$, gdzie: $\delta$ - grubość metalu spawanego elementu, mm.

Jeśli wziąć pod uwagę wpływ takiego ważnego czynnika jak koncentracja wodoru $w$ metalu spoiny [28], to temperatura poprzedniego podgrzewania musi wzrosnąć 
jeszcze o $30 \div 50^{\circ} \mathrm{C}$ [27]. Spawanie takich wielkogabarytowych wyrobów jak konstrukcje kadłubowe, podstawy platform wiertniczych, rury dużej średnicy, z taką temperaturą podgrzewania jest niemożliwie, a wyrób o mniejszych gabarytach odpowiednio do takiej technologii może zwiększyć energo- i pracochłonność o ok. 40\%.

Zmniejszenie koncentracji wodoru dyfundującego w napawanym metalu osiąga się przez poprawę ochrony jeziorka spawalniczego od strony lica, dokładne przygotowanie powierzchni przed napawaniem, wyżarzanie materiału elektrody.

Przy analizie spawalności nie można pominąć faktu, że na skutek działania wysokiej temperatury generowane są odkształcenia cieplne. Więc, przed opracowaniem technologii spawania czy napawania, trzeba wyznaczyć spawalność metalu rodzimego, metalu elektrody i metalu spoiny, prawdopodobieństwo pojawienia się pęknięć odkształcenie spoiny i przedsięwziąć konieczne kroki w celu zmniejszenia czy uniknięcia niepożądanych zjawisk.

Pęknięcia lamelarne pojawiają się w złączach teowych. Przyczynami ich tworzenia są siarczki i krzemiany zlokalizowane w granicach ziaren, a wynikają one z niskiej jakości stali i wysokich naprężeń wewnętrznych, które powstają wskutek braku technologiczności konstrukcji.

Pęknięcia wynikające z powtórnego grzania powstają w obróbce cieplnej i ich powstanie jest związane z spadkiem plastyczności przegrzanego metalu przy ponownym grzaniu do $500 \div 600^{\circ} \mathrm{C}$.

Przyczyną obniżenia plastyczności przegrzanego metalu może być zwiększenie energii granic ziarna pierwotnego powierzchniowo aktywnymi pierwiastkami. W niektórych pracach podkreśla się wpływ sposobu odtleniania i zawartości mikrostopowych pierwiastków. Wyniki badań w tym kierunku są bardzo skomplikowane i często sprzeczne. Na przykład, znikome zwiększenie zawartości miedzi i antymonu (Sb) okazało się niesprzyjające, a cyny - sprzyjające. Przy czym, co ciekawe, odtlenianie aluminium przy jego podwyższonej zawartości do 0,035\% wywiera niesprzyjający wpływ, podczas gdy odtlenianie tytanem - sprzyjający. Zwiększenie zawartości P + Cu + Sn + Pb + As z 0,5 do $1,3 \%$, a także rozmiaru ziarna, zwiększa skłonność materiału do tworzenia pęknięć gorących [29]. Badacze wskazują, że wpływ wanadu i chromu w stalach niskostopowych, w ilości do $2 \%$, jest niesprzyjający.

O wpływie niklu i molibdenu nie ma jednoznacznej opinii, chociaż uważa się, że jest on w zasadzie korzystny.

Dostępna jest wiedza o mechanizmie występowania kruchości wtórnej związanej z procesami segregacji na granicach ziaren szkodliwych domieszek (P, Sn, $\mathrm{Sb}, \mathrm{As}) \mathrm{i}$, wskutek obniżenia kohezyjnej wytrzymałości granic ziaren, przemianą mechanizmu pękania z transkrystalicznego na międzykrystaliczny. Przy czym odnotowuje się bardziej negatywny wpływ kruchości wtórnej na skutek oddziaływania szkodliwych domieszek pierwiastków w SWC, aniżeli w metalu podstawowym, na skutek zwiększenia rozmiaru ziarna austenitu i drastycznego zmniejszenia w wyniku tego powierzchni granic ziaren.

Negatywny wpływ pierwiastków stopowych wzrasta wraz ze zwiększeniem w spoinie ilości manganu i krzemu. Warunek uniknięcia kruchości wtórnej określa się czynnikiem Watanabe [29]:

$$
I=(M n+S i)(P+S n) \cdot 104 \leq 200 \%
$$

Współczynnik Bruskato [30] zaproponowany do oceny kruchości wtórnej metalu spoiny:

$$
X=(10 P+5 S b+4 S n+A s) \cdot 100 \leq 25
$$

Nakamura, a później Ito [29] przeprowadzili próby dla niskostopowej stali z maksymalną zawartością chromu do 1,5\%, które umożliwiły powstanie równania do oceny wpływu składu chemicznego stali na skłonność do tworzenia pęknięć rekrystalizacyjnych.

Parametr oceny skłonności do tworzenia pęknięć $\triangle G$ zgodnie z Nakamurą [29] ma postać:

$$
\Delta G=C r+3,3 M o+8,1 \mathrm{~V}+10 C-2
$$

Ito [29] zaproponował swoje równanie licząc wpływ pierwiastków mikrostopowych na kruchość (PSR):

$$
P S R=C r+C u+2 M o+10 V+7 N b-5 T i-2
$$

Jeśli $\triangle G$ lub $P S R>2$ to materiały te wykazują skłonność do pęknięć kruchych.

Przy ocenie spawalności rola składu chemicznego stali jest dominująca. Według tego wskaźnika w pierwszym przybliżeniu przeprowadza się ocenę spawalności.

Węgiel (C) - jedna z najważniejszych domieszek, decydująca o wytrzymałości, plastyczności, hartowności i innych właściwościach stali. Zawartość węgla w stali do $0,25 \%$ nie obniża spawalności. Większa zawartość C doprowadza do tworzenia hartowniczych struktur w metalu SWC i pojawienia się pęknięć [31].

Siarka (S) i fosfor (P) - szkodliwe domieszki. Podwyższona zawartość siarki doprowadza do tworzenia gorących pęknięć, a fosforu - pęknięć zimnych. Zatem ilość siarki i fosforu w stalach niskostopowych ograni-

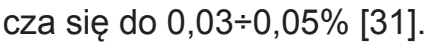

Krzem (Si) jest obecny w stali jako domieszka w ilości do 0,3\% - odtleniacz. Przy takiej ilości krzemu spawal-

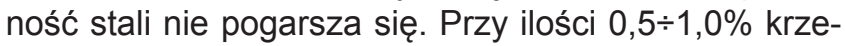
mu (zwłaszcza powyżej 1,2\%) jest możliwe tworzenie tlenków krzemu, pogarszających spawalność stali [31].

Mangan (Mn) przy zawartości do 1,0\% nie pogarsza procesu spawania. Przy spawaniu stali z zawartością manganu w ilości 1,8 $\div 2,5 \%$ jest moźliwe pojawienie hartowniczych struktur i pęknięć w metalu SWC [31].

Chrom (Cr) w stalach niskowęglowych pełni funkcję domieszki w ilości do $0,3 \%$. W stalach niskostopowych jego zawartość wzrasta do $0,7 \div 3,5 \%$. 
W stalach stopowych zawartość waha się od $12 \%$ do $18 \%$, a w wysokostopowych osiąga $35 \%$. Przy spawaniu chrom tworzy węgliki, pogarszające odporność korozyjną stali. Chrom sprzyja tworzeniu trudnotopliwych tlenków, co utrudnia proces spawania [31].

Nikiel (Ni), analogicznie jak chrom, występuje w stalach niskowęglowych w ilości do 0,3\%. W stalach niskostopowych jego zawartość rośnie do 5\%, a w wysokostopowych - do 35\%. W stopach na osnowie niklu jego zawartość jest przeważająca. Nikiel zwiększa właściwości wytrzymałościowe i plastyczne stali, wywiera pozytywny wpływ na spawalność [31].

Wanad (V) w stalach stopowych mieści się w ilości $0,2 \div 0,8 \%$. Podwyższa ciągliwość i plastyczność stali, polepsza jej strukturę [31].

Molibden (Mo) w stali ogranicza się do 0,8\%. Przy takiej zawartości pozytywnie wpływa na właściwości wytrzymałościowe stali i rozdrabnia jej strukturę. Jednak przy spawaniu wypala się i sprzyja tworzeniu pęknięć w metalu napawanym [31].

Tytan i niob ( $\mathrm{Ti}$ i Nb) w stalach odpornych na korozję i żarowytrzymałych pojawiają się w ilości do 1\%. Obniżają podatność stali na korozję międzykrystaliczną, ale niob w stali typu 18-8 sprzyja tworzeniu się pęknięć gorących [31].

Miedź (Cu) występuje w stali jako domieszka (w ilości do 0,3\% włącznie), jako dodatkowy pierwiastek w stalach niskostopowych od 0,15 do 0,5\% i jako element stopowy do 0,8 $\div 1,0 \%$. Podwyższa korozyjne właściwości stali, nie pogarszając spawalności [31].

Ocena spawalności połączeń spawanych z punktu widzenia skłonności do tworzenia pęknięć zimnych nie może być przeprowadzana bez uwzględnienia wpływu wodoru. Na podstawie analizy działania wszystkich trzech głównych czynników (skład chemiczny, gazonasycenie, złożoność konstrukcji), sprzyjających tworzeniu pęknięć zimnych, przyjęto kryterium oceny podatności stali na tworzenie podobnych pęknięć - kryterium tworzenia pęknięć $\left(P_{c}\right)$

$$
P_{C}=P_{c m}+\mathrm{H} / 60+K / 4000
$$

gdzie: $P_{c m}-$ współczynnik, charakteryzujący pękanie wskutek zmian struktury i obliczany wg równania Ito - Bessyo (3); H - ilość wodoru dyfuzyjnego w metalu spoiny; $K$ - współczynnik intensywności złożoności spoiny, obliczony według formuły $D=K \cdot \delta$, gdzie $K_{0}-$ współczynnik, który określa się siłą przemieszczenia skraju połączenia na $1 \mathrm{~mm}$, odniesiony do jednostki grubości lica i długości spoiny; $\delta$-grubość lica, mm.

Wartość współczynnika $K_{0}$ może być obliczona lub wyznaczona eksperymentalnie [33] i wynosi $20 \div 400 \mathrm{kgs} /\left(\mathrm{mm}^{2} . \mathrm{mm}\right)$, przy czym dla próby Tekken zakłada się $69 \mathrm{kgs} /\left(\mathrm{mm}^{2} . \mathrm{mm}\right)[33,34]$.

$\mathrm{Na}$ tworzenie pęknięć zimnych zauważalny wpływ ma działanie naprężeń rozciągających pozostałych po zakończeniu spawania. Naprężenia zależą od grubości połączenia spawanego, typu spawalniczego węzła, a zwłaszcza od złożoności spawanej części konstrukcji. Wartość naprężeń może być wyrażona za pomocą współczynnika intensywności złożoności $K$, przedstawionego wcześniej.

Liczne badania pokazały, że stal jest podatna na tworzenie pęknięć zimnych, jeśli $P_{c}>0,286$.

Z przeprowadzonej analizy literatury wynika, że do tej pory nie wypracowano jednego zdania odnośnie do terminu spawalność i kryteriów jej oceny. Trzeba zaznaczyć, że najpełniejszą systematyzację i analizę pojęcia spawalność różnych autorów i dokumentów przeprowadził Juszczenko [7, 8]. Równania na spawalność w większości wypadków zastępowane są wzorami na skłonność do tworzenia pęknięć. Zatem termin spawalność zamienia się innym słabo określonym terminem. Logika takiego podejścia do spawalności wymaga oceny parametrami, które charakteryzują naruszenie spójności połączenia spawanego (granicą wytrzymałości, plastyczności, pracą zarodkowania i rozprzestrzeniania się pęknięć, współczynnikiem intensywności naprężeń, krytycznym otwarciem pęknięcia), a nie parametrami stopowania złącza spawanego (ekwiwalent węgla). Z innej strony, przez ogromną różnorodność rodzajów i metod spawania, dosyć problematyczna jest lokalizacja pękania właśnie w strefie spawania, żeby charakteryzowało właściwości połączenia spawanego w całości, a nie jego oddzielnych stref - metalu spoiny, linii spawania, strefy wpływu ciepła.

Do dzisiejszych czasów wypracowano pewne zakresy parametrów i kryteria oceny, ale nie został stworzony fizyczny i matematyczny model, umożliwiający analityczną ocenę spawalności. Wynika to ze złożoności procesu, dużej ilości wewnętrznych i zewnętrznych czynników oraz wąskiej analizy procesu przez naukowców.

W trakcie analizy danych literaturowych powstaje wrażenie, że nie należy oczekiwać stworzenia ogólnej numerycznej, matematycznej interpretacji spawalności. Różnorodność materiałów, które poddawane są spawaniu, i procesów spawania, kardynalnie różniących się od siebie pod względem właściwości fizycznych, budzi wątpliwości odnośnie pojawienia się ogólnych kryteriów numerycznych.

\section{Podsumowanie}

Możliwe jest zgodzenie się z pracami [6:8] i rozumienie pod terminem spawalność - właściwości materiałów niezbędnych do tworzenia nierozłącznego połączenia o wysokiej jakości, o zbliżonych właściwościach fizykochemicznych do materiału rodzimego, co pozwala tworzyć konstrukcje do odpowiedzialnego przeznaczenia.

Można przy tym oceniać spawalność każdego materiału i dobierać sposób spawania z uwzględnieniem już opracowanych i omówionych w przeglądzie kryteriów, poza tym w każdym konkretnym przypadku można warunkować wymogi konieczne do uzyskania połączenia spawanego. 


\section{Literatura}

[1] ISO 581:1980 Weldability-Definition. General information

[2] BS 499-1:2009 Welding Terms and Symbols. Glossary for Welding, Brazing and Thermal Cutting.

[3] DIN 8528-1. Spawalność metali. Definicje.

[4] Rosyjska norma państwowa GOST 29273-92 (ISO 581-80). Spawalność. Definicje. Moskwa: 1999.

[5] Ukraińska norma państwową DSTU 3761.1-98. Spawanie i pokrewne procesy. Cz. 1. Spawalność. Definicje.Wprowadz.: 01.07.99. Kijów, 1999, s.2.

[6] Hriwniak I.: Spawalność stali. Moskwa: Maszynostrojenie, 1984, s.216

[7] Weldability of materials, K.A. Yushchenko et al. - Kyiv: E.O. Paton Electric Welding Institute, Ukraine. IIW-Doc.VI-84207.

[8] Yushchenko K.A, Derlomenko W.W.: Analiza nowoczesnych podejść do spawalności. Automatic welding, 2005, N, s.9-13.

[9] Spawalność pol spokojnych stali / pod redakcją. A. Je. Asnisa. Kijow: IES im. Je.O. Patona, 1976, s.344.

[10] Szorszorow M. H., Czernyszowa T.A., Krasowskii A.I:. Wypróbowania metali na spawalność. Moskwa: Metallurgia, 1972, s.240.

[11] Musijaczenk W.F., Michoduj L.I.:Lukowe spawanie wysoko wytrzymałościowych stopowanych stali. - Moskwa: Mashynostrojenije, 1987, s.79.

[12] Herold X.:Nowe aspekty w badaniach spawalności - osnowa dla technologii i gwarantowania jakości procesu spawania // Automatic welding, 2008, N11, s.143-150.

[13] Babenko E.G, Kazanowa N.P.: Obliczenia reżymów spawania elektrycznego i napawania// KPI, Katedra "Technologia metali", 1999.

[14] http://www.xiron.ru/content/view/21389/28/

[15] Mazel A.G. Nowoczesne sposoby spawania rurociągów stopieniem, K. 1979, 256c.

[16] http://metalloved.com/spravochnik/svarochnye_raboty/fizicheskaya_svarivaemost/.

[17] Pod red. Ju P.Solncewa, Metale i stopu. Roz. 4. Właściwości technologiczne. Poradnik, NPO «Profesional», Sankt-Peterburg, 2003, s.1076

[18] Pod redakcja W.W. Stepanowa, Poradnik spawalnika., Faktory technologiczne, które wpływają na spawalność.- Moskwa: Mashynostrojenije, 1975, s.520
[19] Porad. wyd./ pod red. E.L Makarowa; Spawanie i spawane materiały: W 3-h t. T. 1. Spawalność materiałów, Moskwa: Metallurgia, 1991, s.528

[20] E.G. Babenko, N.P. Kazanowa. Obliczenia reżymów spawania elektrycznego i napawania// Poradnik metodyczny, 1999, $200 \mathrm{~s}$.

[21] Hasui A., Morigaki O., Napawanie i natryskiwanie/ Tłumaczenie W.N. Popowa; Pod red. W.S. Stepina, I. G. Szesterkina. - Moskwa: Mashynostrojenije, 1985, s.240

[22] G.B. Olson, M. Cohen, A general mechanism of martensitic nucleation: Parts I, II and III, Metallurgical Transactions A, 7A (1976) 1897-1923.

[23] IIWDoc.IX-535-67, 1967.

[24] Ito I., Bessyok.: IIWDoc. IX-576-68, 1967.

[25] Yurioka N., Ohsita S., Tamehiro P. : Pipe-line welding in the 80s. AWRA symp. March 1981, 1.

[26] Grabin W.F., Golowko W.W., Solomijszuk T.G., Honczarenko E.I., Kostin W.A. Analiza skladu strukturalnego metalu spoin, wykonanych drotami spawalniczymi ferytyczno-perlityczny$\mathrm{mi} / /$ Automatic welding, 2003, N8, s.18-23

[27] D. Seferian. Metalurgia spawania . - Moskwa: Metallurgia,1963, s.338

[28] I.Hriwniak, F. Macuda. Metalofizyczne badania martenzytyczno-austenitycznej składowej metalu strefy wpływu ciepła wysoko wytrzumalych nisko stopowych stali // Automatic weIding, 1999- N 3, s.22-30.

[29] http://ruswelding.com/treschiny_povtornogo_nagreva.html

[30] Lifszic L.S, Hakimow A.N., Metaloznawstwo spawania i obróbka cieplna złącz spawanych. - 2-gie wydanie, przerobione. - Moskwa: Mashynostrojenije, 1989, s.336.

[31] http://weldzone.info/technology/manual-arc-welding/251kons6

[32] W.W. Kwasnickii. Teoria procesów spawania. Badanie fizykochemicznych i metalurgicznych procesów i zdolności metali do spawania. Poradnik szkoleniowy. -Mikolajow: UDMTU, 2002, s. 184

[33] Spanie w budownictwie maszyn: Poradnik w 4 t. - Moskwa: Mashynostrojenije, 1978. -T.1. s. 504, 1979. T.3, $567 \mathrm{~s}$.

[34] W.I. Makhnenko. Komputerowe modelowanie procesów spawania // Nowoczesne materiale znawstwo XXI wieku. -Kijow: Naukowa dumka думка, 1998, s.108-124.

\section{PLANY SPAWANIA - TEORIA I PRAKTYKA - JACEK SLANIA}

\section{Cena}

Cena 1 egzemplarza książki Jacka Słani:

Plany spawania - teoria i praktyka

80 zł (w tym 5\% VAT)

\section{W celu zamówienia książki w Redakcji należy wypełnić formularz zamieszczony obok i przesłać go w formie faksu, skanu lub listu na adres:}

REDAKCJA - Przegląd Spawalnictwa AW SIMP

ul. Świętokrzyska 14a, 00-050 Warszawa tel./fax: 2282725 42, 223361479

e-mail: pspaw@ps.pl

Wpłaty należy dokonać na rachunek bankowy: Bank BPH S.A. Oddział w Warszawie 45106000760000320000431836

\section{Zamawiam książkę Plany spawania - teoria i praktyka}

w Redakcji Przegląd Spawalnictwa w ilości .... egz.

Imię i nazwisko

Firma

Adres

NIP

Kontakt do osoby zamawiającej:

Oświadczam, że jestem podatnikiem VAT i upoważniam firmę do wystawienia faktury bez podpisu 